\title{
Isolasi Dan Identifikasi Morfologi Mikrobia Indigenous Pada Limbah Kulit Singkong
}

\author{
Esna Dilli Novianto, Candarisma Dhanes Noor Viana, Mita Nur Jannah, Dita Widyastuti \\ Program Studi Agroteknologi, Fakultas Pertanian Universitas Tidar \\ Email: dilli.novianto@untidar.ac.id
}

\begin{abstract}
Abstrak
Industri olahan makanan berbahan dasar singkong di Kota Magelang tidak hanya memberikan dampak positif terhadap kesejahteraan, tetapi juga dampak negatif yang perlu mendapat perhatian khusus salah satunya mengenai limbah. Selain kulit singkong, penggunaan plastik sebagai pembungkus gethuk menambah cemaran di lingkungan sekitar. Penelitian ini mengusung ide biokonversi limbah organik padat kulit singkong menjadi bioplastik dengan memanfaatkan mikrobia indigenous sebagai agensia pengkonversi. Pada tahap awal, mikrobia indigenous yang mampu hidup pada limbah kulit singkong di isolasi dan diidentifiaksi secara morfologi terlebih dahulu. Kulit singkong dari berbagai kawasan industri gethuk dikumpulkan dan dimasukkan ke dalam erlenmeyer yang berisi media NB selama 2×24 jam. Isolasi mikrobia menggunakan media NA sampai mendapatkan kurtur murni dan diidentifikasi morfologi. Hasil penelitian menunjukkan ada 7 isolat mikrobia yang mampu hidup pada limbah kulit singkong yaitu KSSK 01, KSSK 02, KSSK 03, KSSK 05, KSSK 06, KSDM 01, dan KSDM 04. Semua mikrobia ini perlu diuji lanjut kemampuannya sebagai agen pengkonversi limbah kulit singkong.
\end{abstract}

Kata kunci: bioplastik, limbah kulit singkong, mikrobia

\begin{abstract}
The cassava-based food processing industry in Magelang City does not only have positive impacts, but also negative impacts that need special attention, one of which is waste. Apart from cassava peels, the use of plastic as a wrapper for gethuk adds to the pollution of the surrounding environment. This study aims to examine the idea of bioconversion from cassava peels into bioplastics by utilizing indigenous microbes as conversion agents. In the initial stage, indigenous microbes that can live on cassava peel waste were isolated and identified morphologically first. Cassava peels from various industrial areas of gethuk were collected and put into an erlenmeyer containing NB media for $2 \times 24$ hours. Microbial isolation using NA media to obtain pure microbial culture and morphology identified. The results showed that there were 7 microbial isolates that were able to live on cassava peel waste, namely KSSK 01, KSSK 02, KSSK 03, KSSK 05, KSSK 06, KSDM 01, and KSDM 04. All of these microbes need to be further tested for their ability as waste conversion agents of cassave peels.
\end{abstract}

Keywords : bioplastic, cassava peel waste, microbes

\section{PENDAHULUAN}

Salah satu olahan makanan yang terkenal di Kabupaten Magelang adalah gethuk. Adanya agroindustri "gethuk" memberikan dampak positif antara lain meningkatkan pendapatan petani sebagai supplier bahan baku, penyerapan

http://ejournal.urindo.ac.id/index.php/pertanian

Article History :

Sumbitted 10 Desember 2020, Accepted 30 Desember 2020, Published 31 Desember 2020 
tenaga kerja, dan meningkatkan perekonomian daerah secara umum. Namun demikian agroindustri gethuk menyisakan kulit singkong sebagai limbah organik padat yang mencemari lingkungan. Selain itu pengemasan gethuk menggunakan plastik sebelum dijual juga menimbulkan dampak lingkungan yang serius karena residu limbah plastik tidak dapat di degradasi dalam waktu singkat. Jika hal ini dibiarkan maka peningkatan aktivitas agroindustri gethuk akan meninggalkan permasalahan lingkungan yang semakin besar. Untuk mengatasi masalah tersebut inovasi pengelolaan limbah perlu dilakukan. Konversi limbah padat organik kulit singkong menjadi plastik biodegradable dapat dijadikan solusi yang tepat.

Teknologi konversi kulit singkong menjadi plastik biodegradable sudah pernah dilakukan sebelumnya [1,2]. Limbah kulit singkong diberi campuran gliserol hingga mendapatkan komponen plastik. Namun metode tersebut masih memiliki beberapa keterbatasan diantaranya dibutuhkan limbah kulit singkong dalam jumlah besar untuk mendapatkan komponen penyusun plastik biodegradable. Cara lain yang dapat dilakukan adalah dengan menggunakan jasad mikrobia $[3,4]$. Penelitian Budde et al. berhasil mengisolasi senyawa Poli Hidroksi Alkanoat (PHA), suatu komponen penyusun bioplastik dari bakteri Ralstonia eutropha yang ditumbuhkan pada limbah minyak [3]. Penelitian lain berhasil mendapatkan mikrobia yang mampu menimbun PHA di dalam selnya [4]. Penggunaan mikrobia sebagai piranti produsen bioplastik dari organisme hidup, diketahui lebih mudah, lebih murah dan lebih ramah lingkungan dibandingkan dengan metode kimiawi [5]. Mikrobia penghasil bioplastik atau selanjutnya disebut dengan bioplastic producer microbes banyak ditemukan pada limbah-limbah organik seperti limbah perkebunan, sampah organik pasar, sampah buah-buahan dan lain sebagainya. Kulit singkong dan limbah organik agroindustri gethuk lainnya mengandung komponen polisakarida yang tinggi, sehingga ada potensi ditemukannya bioplastic producer microbes yang indigenous.

Hingga saat ini potensi bioplastic producer microbes pada limbah kulit singkong di Magelang belum pernah digali. Namun demikian sebelum mendapatkan kandidat mikrobia yang tepat, pada penelitian ini dilakukan isolasi dan identifikasi morfologi mikrobia indigenous yang terdapat pada limbah kulit singkong. Kemampuan isolat mikrobia dalam mengubah senyawa polisakarida menjadi PHA hanya dapat diperoleh pada jasad yang mampu bertahan hidup pada limbah [6]. Hasil penelitian ini diharapkan dapat digunakan sebagai rekomendasi bagi para pelaku agroindustri gethuk dalam pengelolaan limbah menjadi produk bernilai ekonomi, sehingga dapat mewujudkan agroindustri gethuk yang ramah lingkungan dan mendukung pembangunan berkelanjutan.

\section{METODE}

A. Pemilihan lokasi 


\section{Jurnal IImiah Respati}

Pemilihan lokasi penelitian dilakukan secara sengaja atau purposive yaitu di berbagai produsen gethuk di Kabupaten Magelang.

B. Waktu dan Lokasi Penelitian

Penelitian ini akan dilaksanakan pada bulan Februari hingga Agustus Tahun 2020. Pelaksanaan penelitian dibagi menjadi dua tahapan. Tahapan pertama yaitu melalui pengambilan sampel di berbagai produsen gethuk di Kabupaten Magelang. Tahap kedua, akan dilaksanakan di laboratorium Fakultas Pertanian Universitas Tidar untuk mengidentifikasi mikrobia.

\section{Alat dan Bahan}

Alat yang digunakan pada penelitian ini adalah alat pengambil sampel tanah, plastik ziplock, autoklaf (Memmert, Germany) untuk sterilisasi alat dan media, Oven pengering (Memmert, Germany), timbangan digital, Inkubator (Memmert, Germany) alat standar isolasi dan inokulasi berupa peralatan gelas dan jarum ose, Mikroskop cahaya untuk pengamatan pada pengecatan gram.

Bahan yang digunakan pada peneltiian ini meliputi Nutrien Agar dan Nutrien Broth sebagai media dasar isolasi dan inokulasi, satu paket cat gram berupa kristal violet, larutan Mordan, Alkohol 70\% dan safranin.

\section{Isolasi Bakteri indigenous}

Metode isolasi seperti yang dilakukan oleh Chen et al. (2016) dengan modifikasi [6]. Sebanyak 15 gram kulit singkong dimasukkan ke dalam $100 \mathrm{~mL}$ media NB yang telah disterilisasi. Campuran digoyang selama $2 \times 24$ jam di shaker pada suhu kamar. Setelah itu, campuran diambil sebanyak $1 \mathrm{~mL}$ dan dimasukkan ke dalam media $9 \mathrm{~mL}$ akuades steril untuk pengenceran bertingkat. Hasil pengenceran bertingkat diambil sebanyak 1 $\mathrm{mL}$ dan ditumbuhkkan pada media padat NA secara pour plate. Hasil isolasi diinkubasikan pada suhu kamar selama $2 \times 24$ jam.

Untuk mendapatkan kultur murni, setiap koloni yang berbeda ditumbuhkan kembali pada media NA secara streak plate untuk mendapatkan koloni tunggal (pure culture). Hasil kultur murni dilakukan reinokulasi secara periodik dan digunakan untuk karakterisasi mikorbia.

\section{E. Karakterisasi Morfologi}

Mikrobia diamati karakter morfologi berupa bentuk koloni pada media agar padat, agar miring dan agar tegak, warna koloni, dan pengecatan gram.

\section{F. Pewarnaan Gram}

Pewarnaan gram menggunakan kristal violet (Gram A), larutan iod (Gram B), alkohol 70\% (Gram C) dan safranin (Gram D). Pengecatan diawali dengan fiksasi mikrobia dengan dilewatkan pada api bunsen kemudian dilakukan pengecatan secara urut dengan waktu 1 menit, 1 menit, $1 / 2$ menit dan 2 menit. Penampakan sel mikrobia diamati dengan mengunakan mikroskop cahaya. Kumpulan sel dengan warna ungu menunjukkan gram positif, sedangkan kumpulan sel bewarna merah menunjukkan gram negatif [7] 


\section{HASIL DAN PEMBAHASAN}

1. Sampling Limbah Kulit Singkong

Sampel limbah kulit singkong diambil di beberapa titik daerah di Kabupaten Magelang dan Kota Magelang. Pemilihan tempat dilakukan secara acak dengan membawa informasi data dari Dinas Perindustrian Kota Magelang. Metode wawancara langsung dengan penggiat industri singkong, kebutuhan dasar yang digunakan, serta limbah domestik yang dihasilkan per harinya ikut diambil datanya secara komprehensif untuk mengetahui aliran supply chain agroindustri singkong di kawasan Magelang. Responden yang bersedia diwawancarai adalah sebanyak 28 responden. Limbah kulit singkong diambil secara acak dari lokasi wawancara.

\section{Isolasi Mirobia Kulit Singkong}

Limbah didiamkan terlebih dahulu selama satu minggu di suhu ruang, kemudian diambil sebanyak 15 gram limbah kulit singkong dan dimasukkan ke dalam erlenmeyer yang berisi media NB steril. Inkubasi dilakukan selama 2x24 jam pada suhu ruang dengan tetap menggoyang shaker pada kecepatan 50 - 70 rpm. Setelah selesai, sampel rendaman diambil sebanyak $1 \mathrm{~mL}$ untuk digunakan sebagai sumber pengenceran bertingkat. Isolasi mikrobia dilakukan dengan metode pour plate untuk mendapatkan mikrobia apa saja yang berhasil tumbuh di kompartemen limbah singkong. Selanjutnya, setiap koloni yang tumbuh pada cawan petri diambil dan dimurnikan dengan metode streak plate untuk mendapatkan isolat murni mikrobia indigenous limbah kulit singkong. Seluruh isolat yang didapatkan di inokulasi setiap 3 hari sekali dalam rangka peremajaan bakteri. Beberapa isolat yang berhasil tumbuh pada media NA ditunjukkan pada Gambar 1.

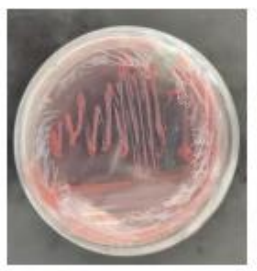

i

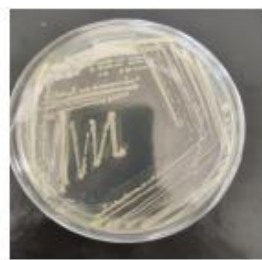

ii

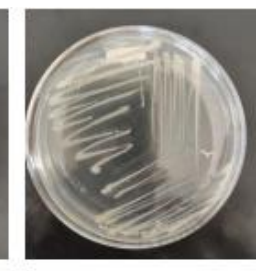

iii
Gambar 1. Penampakan isolat kultur murni mikrobia indigenous yang mampu hidup pada limbah kulit singkong: (i) isolat KSDM 01; (ii) isolat KSSK 01; (iii) isolat KSSK 03.

Isolat yang mampu tumbuh pada media NA adalah isolat terpilih yang mampu tumbuh pada limbah kulit singkong. Mikrobia menggunakan polisakarida pada kulit singkong sebagai sumber karbon sehingga mampu tumbuh dan berkembangbiak pada limbah tersebut [8]. Akumulasi polisakarida pada mikrobia yang berlebih pada spesies tertentu dapat tersimpan sebagai poli hidroksi alkonoat (PHA) di dalam sel $[9,10]$. Molekul ini kemudian diketahui dapat digunakan sebagai bahan dasar pembuatan bioplastik [11,12]. Jadi isolat mikrobia yang hidup pada limbah kulit singkong memiliki potensi sebagai bioplastic producer microbes.

3. Karakteristik Morfologi Isolat Mikrobia Kulit Singkong

Karakteristik morfologi isolat mikrobia yang diamati adalah pertumbuhan pada media agar 


\section{Jurnal IImiah Respati}

miring, pertumbuhan pada media agar tegak, pengecatan gram. Adapun data lebih komprehensif mengenai hasil pengamatan ini disajikan pada tabel berikut ini:

Tabel 1. Pengamatan karakteristik morfologi isolat mikrobia yang mampu tumbuh pada limbah kulit singkong

\begin{tabular}{|c|c|c|}
\hline No & Isolat & Karakteristik \\
\hline 1 & KSSK 01 & $\begin{array}{l}\text { Koloni berbentuk } \\
\text { bulat, berwarna putih, } \\
\text { pada pewarnaan gram } \\
\text { menunjukkan warna } \\
\text { ungu (gram positif) }\end{array}$ \\
\hline 2 & KSSK 02 & $\begin{array}{l}\text { Koloni berbentuk } \\
\text { bulat, berwarna putih } \\
\text { kekuningan, pada } \\
\text { pewarnaan gram } \\
\text { menunjukkan warna } \\
\text { ungu (gram positif) }\end{array}$ \\
\hline 3 & KSSK 03 & $\begin{array}{l}\text { Koloni berbentuk } \\
\text { bulat, berwarna putih } \\
\text { krem, pada pewarnaan } \\
\text { gram menunjukkan } \\
\text { warna ungu (gram } \\
\text { positif) }\end{array}$ \\
\hline 4 & KSSK 05 & $\begin{array}{l}\text { Koloni berbentuk } \\
\text { bulat, berwarna putih } \\
\text { kekuningan } \\
\text { transparan, pada } \\
\text { pewarnaan gram } \\
\text { menunjukkan warna } \\
\text { ungu (gram positif) }\end{array}$ \\
\hline 5 & KSSK 06 & $\begin{array}{l}\text { Koloni berbentuk } \\
\text { bulat, berwarna putih } \\
\text { krem transparan, pada } \\
\text { pewarnaan gram } \\
\text { menunjukkan warna }\end{array}$ \\
\hline
\end{tabular}

ungu (gram positif)
6

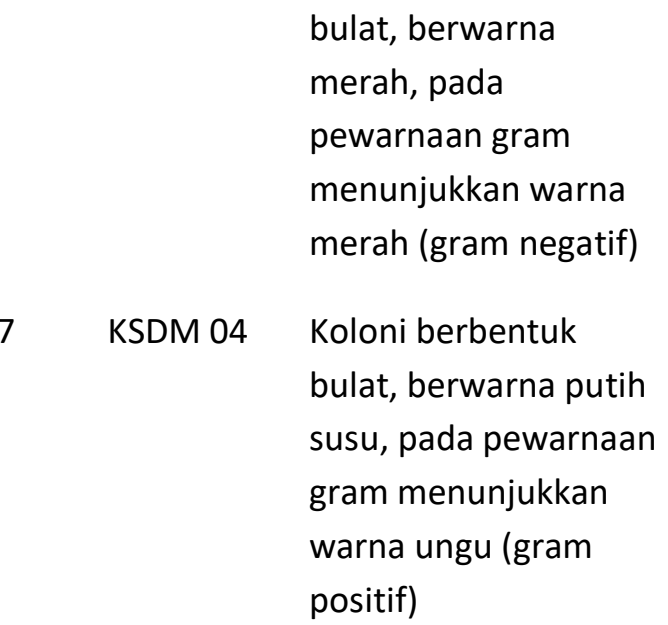

Hasil penelitian ini mendapatkan 7 isolat utama yang berbeda dan mampu tumbuh pada limbah kulit singkong. Ketujuh isolat ini adalah KSSK 01, KSSK 02, KSSK 03, KSSK 05, KSSK 06, KSDM 01, dan KSDM 04. Isolat mikrobia yang dihasilkan dapat dipastikan berpotensi sebagai agen pengkonversi limbah organik industri singkong menjadi bioplastik. Meskipun demikian, penelitian lanjutan mengenai kemampuan isolatisolat tersebut dalam mengakumulasi PHA masih perlu diuji lebih lanjut.

\section{SIMPULAN}

Didapatkan tujuh isolat yang mampu hidup pada limbah kulit singkong yaitu isolat KSSK 01, KSSK 02, KSSK 03, KSSK 05, KSSK 06, KSDM 01, dan KSDM 04. Kemampuan ketujuh isolat bertahan hidup di lingkungan limbah ditengarai karena menggunakan polisakarida yang terdapat pada kulit singkong sebagai sumber karbon. Akumulasi polisakarida dalam jumlah banyak di dalam sel dapat membentuk PHA sebagai bahan 
dasar bioplastik. Namun demikian hasil penelitian ini masih perlu uji lanjutan untuk mengetahui kemampuan masing-masing isolat dalam mengakumulasi PHA.

\section{PENUTUP}

Ucapan terima kasih diberikan kepada Kementerian Riset dan Teknologi / Badan Riset dan Inovasi Nasional atas dukungan dana yang diberikan lewat program Penelitian Dosen Pemula Tahun Anggaran 2020.

\section{DAFTAR PUSTAKA}

Suryati, Meriatna, Marlina. 2016. Optimasi proses pembuatan bioplastik dari pati limbah kulit singkong. Jurnal Teknologi Kimia Unimal 5:1 (2016) 78 - 91.

Kelibay, M.F. Skripsi Sarjana, Pengaruh penambahan gliserol pada pembuatan bioplastik dari limbah ampas tahu dan kulit singkong. IAIN Ambon, 2020.

Budde, C.F., Sebastian R.L., Laura B.W., Chokyun R., Anthony J.S. 2011. Production of Poly (3- Hydroxi 5. Burdon, K.L., Stokes, J.C. Kimbrough, C.E.1942. Studies of the common aerobic spore forming bacilli staining for fat with Sudan Black B-stain. Journal of bacteriology (43):717- 724.

Pfeifer, D \& Jendrossek, D. 2013. PhaM is the physiological activator of poly (3hydrozibutirate) (PHB) synthase (PhaC1) in Ralstonia eutropha. Applied and Environmental Microbiology p. 555- 563.
Bath, S., Nicith, K. R., Kiran, Y., Nagendra, M., Pallavi, S.L., Shreya, S., Pruthvl, B., Madhumita, G.D. 2017. Production of Bioplastic from microorganisms. International Journal of Advanced Research 5(2): 2710-2716.

Chen, G.Q., X.R. Jiang, Y. Guo. 2016. Synthetic biology of microbes synthesizing polyhydroxyalkanoates (PHA). Synthetic and Systems Biotechnology 1 (2016) 236242.

Ali, I., N. Jamil. 2016. Biosynthesis and Characterization of Poly3-hydroxyalkanote (PHA) from Newly Isolated Bacterium Bacillus sp. AZR-1. Iran J Sci Technol Trans Sci.

Li, R., P. Gu, X. Fan, J. Shen, Y. Wu, L. Huang, Q. Li. 2018. Isolation and Characterization of PHA-Producing Bacteria from Propylene Oxide Saponification Wastewater Residual Sludge. Appl Biochem Biotechnol.

A. Choonut, P. Prasertsan, S. Klomklao, K. Sangkharak. 2020. Bacillus thermoamylovorans- Related Strain Isolated from High Temperature Sites as Potential Producers of Medium-ChainLength Polyhydroxyalkanoate (mcl-PHA). Current Microbiology.

Khanna S, Srivastava A.K. 2005. Recent advances in microbial poly hydroxy alkanoates. Process Biochem 40(2):607-619.

Pulungan, M.H., N.Hidayat, A.Wafa, K.Wardina. 2018. Pendayagunaan Pati Singkong dan 
Jurnal Ilmiah Respati

Tepung Kulit Singkong Sebagai Bahan

Pembuatan Plastik Biodegradable (Kajian

Rasio Pati Singkong dan Tepung Kulit

Singkong). Prosiding Seminar Nasional

Kulit, Karet dan Plastik ke-7.
Amirul, A.A., Yahya, A.R.M., Suresh, K., Azizan, M.N.M and Majid, M.I.A. 2008. Biosynthesis of poly (3-hydroxy butyrateco-4-hydroxybutyrate) copolymer by Cupriavidus sp. USMAA1020 isolated from lake Kulim Malaysia. Bioresour Technol (99):4903-4909. 